\title{
Value, Growth and Divergence of Opinion in Emerging Markets: Chinese Evidence
}

\author{
Man Li \\ Accounting and Finance (UWA Business School) \\ The University of Western Australia \\ 35 Stirling Highway, CRAWLEY WA 6009. Australia \\ Mike Dempsey \\ School of Economics, Finance and Marketing \\ RMIT University, GPO box 2476, Melbourne, VIC 3001, Australia
}

\begin{abstract}
The issue of whether value stocks outperform growth stocks as predicted by the Fama and French three-factor model is of continuing interest and debate. In this paper, we examine (a) whether value stocks outperform growth stocks in a developing market (the Shanghai and Shenzhen stock exchanges in their formative years) and (b) whether such outperformance can be attributed to a risk factor as captured by analysts' divergence of opinion. We establish two major findings. First, we show that book-tomarket, sales-to-price, earnings-to-price, and cash-flow-to-price are significant in explaining expected returns for Chinese equities, and thus conclude that value stocks generate returns superior to growth stocks. Our second major finding is that the superior performance of value stocks is related positively to investor uncertainty as proxied by their divergence of opinion

JEL Classification: G10, G15, G20

Key words: Chinese stock market; Value stocks; Growth stocks; Divergence of opinion.
\end{abstract}

\section{INTRODUCTION}

The Fama and French three-factor model $(1996,1997)$ proposes that value stocks outperform growth stocks for equities in US markets. The model has subsequently been substantiated in alternative markets, such as Chan et al. (1991) in Japan, and Gharghori et al. (2012) in Australia. An interesting question that remains is whether or not a similar effect might be observed in developing markets. To address this question, we focus on the performances of the Shanghai and Shenzhen stock exchanges in their formative years. An additional question in relation to the Fama and French three-factor model is whether the outperformance of value stocks over growth stocks might be related to risk exposure. In response, we also investigate whether superior performance is related to investors' divergence of opinion. That is, we test whether the superior return of value stocks is a reward for greater uncertainty about future growth in earnings.

Motivations for this study stem from the fact that empirical research on the value-growth effect has been focused on developed markets (Lakonishok, Shleifer and Vishny (hereafter LSV) 1994 in U.S; Chan et al., 1991 in Japan; and Gharghori et al., 2012 in Australia). In a seminal paper, Fama and French (hereafter FF) (1992) document that B/M is strongly positively related to stock returns in the US. Similarly, LSV (1994) find that value strategies-that is, investing in firms that have high $\mathrm{B} / \mathrm{M}, \mathrm{E} / \mathrm{P}$ or $\mathrm{C} / \mathrm{P}$ values-have historically generated higher returns in the United States. Kwag and Lee (2006) also state that value stocks consistently outperform 
growth stocks through the business cycle. Bhandari (1988) finds that returns are positively related to the ratio of debt-to-equity (D/E) when controlling for beta and firm size (both including and excluding January). For Japanese stocks, Chan et al. (1991) examine the crosssectional relationship between average returns and fundamental variables, including firm size, book-to-market equity $(\mathrm{B} / \mathrm{M})$, earnings-to-price $(\mathrm{E} / \mathrm{P})$ and cash-flow-to-price $(\mathrm{C} / \mathrm{P})$. They show that stocks with higher ratios generate higher returns than stocks with lower ratios. Leledakis and Davidson (2001) show that sales-to-price (S/P) is highly significant in explaining the cross-sectional variation in equity returns in the UK.

Although there is consensus on the existence of superior returns for value stocks in developed markets, the explanation for these superior returns remains an open question. For instance, FF $(1993,1996)$ argue that higher returns are compensation for holding higher fundamental risk, in line with the intertemporal capital asset pricing model (ICAPM) ${ }^{1}$ of Merton (1973) or the arbitrage pricing theory (APT) ${ }^{2}$ of Ross (1976). They show that value stocks (high B/M, E/P and $\mathrm{C} / \mathrm{P}$ ) tend to have persistently low earnings, and that growth stocks (low $\mathrm{B} / \mathrm{M}, \mathrm{E} / \mathrm{P}$ and $\mathrm{C} / \mathrm{P}$ ) tend to have persistently high earnings. FF (1998) find that value stocks also have higher returns than growth stocks in global markets.

In contrast, LSV (1994) suggest that investors appear to consistently underestimate future growth rates of value stocks, and therefore underprice them. The outcome is that value stocks outperform growth stocks. Using survey data on forecasts by stock market analysts, La Porta (1996) finds that value stocks earn high returns due to the fact that the market is excessively pessimistic about the earnings of value stocks and excessively optimistic about the earnings of growth stocks. La Porta, Lakonishok, Shleifer and Vishny (1997) examine the market's reaction to earnings announcements and show that there are significant differences in earnings announcement returns between value stocks and growth stocks due to earnings surprises.

In an important paper, Doukas, Kim and Pantzalis (2004) document that divergence of opinion may also play an important part in explaining the superior returns of value stocks. Specifically, they document that value stocks are exposed to greater investor disagreement than growth stocks. Their findings imply that the return advantage of value strategies is a reward for the greater disagreement about their future growth in earnings. Although both theoretical and empirical research has investigated whether divergence of opinion plays a significant role in explaining stock returns, the evidence on this relationship remains mixed and inconclusive.

In a landmark paper, Miller (1977) hypothesizes that stock prices are biased to the valuations of optimists rather than pessimists as pessimistic investors do not participate in the market due to short-sales constraints. By documenting that high earnings forecast dispersion is associated with low stock returns, Ackert and Athanasakkos (1997), Dische (2002) and Diether et al. (2002) provide evidence in support of Miller's conjecture; while Hintikka (2008) and Leippold and Lohre (2008) find that high dispersion stocks also underperform in many European markets. Chang, Cheng and Yu (2007) test Miller's (1977) hypothesis for equities listed in Hong Kong and also support Miller's conjecture. However, Diamond and Verrecchia (1987) challenge Miller (1977) and argue that if traders have rational expectations, short-sale constraints do not lead to biased prices. Berkman, et al. (2009) state that Miller's (1977)

The ICAPM presents expected returns as the sum of a market risk premium and a package of risk premiums multiplied by the beta of the security or portfolio with respect to the particular factor premium.

The arbitrage pricing model (APT) proposed by Ross (1976) predicts that the return on a security is proportional to several factors, in addition to market risk. 
hypothesis cannot persist indefinitely as periodic announcements reduce the differences of opinion among investors and thus stock prices move closer to their fundamental values.

Contradicting Miller (1977) but consistent with both Williams (1977) and Varian (1985) who argue that divergence of opinion proxies for risk, Doukas et al. (2006a) find a positive and significant relationship between divergence of opinion and future stock returns. Doukas et al. (2002) document that value stocks display higher forecast errors and larger downward forecast revisions. Douks, Kim and Pantzalis (2004)link the divergence of opinion among investors and the performance of value stocks and find that divergence can explain the return differences between value and growth stocks for U.S. equities. Doukas et al. (2006b) show that overvaluation occurs when divergence is low and analysts' predictions are optimistic.

It is important to note that little, if any, has been published on whether value strategies outperform growth strategies outside developed markets. In this regard, we provide much needed out-of-sample evidence and in doing so we respond to the data-snooping hypothesis of Black (1993) and Mackinlay (1995) and the survivorship bias hypothesis of Kothari et al. (1995). As far as the relationship between divergence of opinion and the performance of value stocks is concerned, we are aware of only one published paper by Doukas et al. (2004) that addresses this issue. Our study is thereby motivated to shed new light on the role of divergence of opinion in explaining the superior performance of value stocks. Specifically, we investigate whether value stocks outperform growth stocks for equities listed in the Shanghai and Shenzhen stock exchanges and whether superior performance is related to investors' divergence of opinion. This begs the question - Why China? We study the Chinese market for the following reasons.

Previous research into the Chinese stock market has focused mainly on the effect of privatization, the underpricing of Chinese IPOs and the price differentials among different classes of shares (Sun and Tong 2003; Ma and Faff 2006). Only recently has the behavior of stock returns relative to fundamental variables received attention. Drew et al. (2003) argue that the market beta and firm size effect are priced, but B/M appears to be negatively related to stock returns. Eun and Huang (2007) find that although market risk is not priced, firm size and $\mathrm{B} / \mathrm{M}$ are systematically related to stock returns; and there is no January effect, ${ }^{3}$ but August sees the highest average return of the year. Notwithstanding market imperfections, they conclude that Chinese stocks are actually priced rather rationally. Although they evaluate the abilities of firm specific variables to explain stock returns, they do not directly address the value/growth effect in China. The mixed results of prior research motivate this study to further investigate whether firm size and B/M are pervasive risk factors in the Chinese market; and whether other variables have significant power in explaining returns in China.

The Chinese stock market has grown rapidly since its inception in the early 1990s and is now among the most important emerging markets. ${ }^{4}$ This rapid growth has been largely due to the

The January effect (that stock returns are significantly higher in January than in the rest of the year) is perhaps the best-known seasonal effect in developed markets.

At the end of 2007, the SHSE was ranked the sixth largest market in the world in terms of market capitalization; the SZSE was ranked the twentieth largest; while China's total market capitalization (both SHSE and SZSE) was around 32 trillion RMB, the second largest market only behind the U.S. To complement the two main exchanges, the Small and Medium (SME) Board was opened in June 2004 in SZSE where small and medium enterprises have lower entry barriers to be listed, especially for new high-tech firms. Similarly, the Special Treatment (ST) Board was established in 2001 for the delisted firms on both SHSE and SZSE (http://www.world-exchanges.org; http://www.szse.cn; http://www.sse.com.cn). 
steady flow of new listed firms and the vast reduction of state-owned shares. Almost all publicly listed firms in China were formerly strong large and medium state owned enterprises (SOEs). An initial purpose of opening the Shanghai and Shenzhen stock exchanges was to raise funds for SOEs. The ownership structure of former SOEs has thus resulted in a mixed structure ownership of listed firms, which is a distinct characteristic of the Chinese market (Sun and Tong, 2003). The outcome is that there are several types of shares in the Chinese stock market: state shares and legal person shares, which cannot be traded and owned by the central government, local governments, or government-owned enterprises; A shares, traded by domestic investors, the Qualified Foreign Institutional Investors (QFII); and B shares issued to foreign investors. ${ }^{5}$ The non-tradable share-holders are entitled to the same voting and cash flow rights as the holders of tradable shares but they cannot trade their shares publicly even if the company is listed (Poon et al. 1998). There were about two thirds non-tradable shares in China's market before the non-tradable share reform in 2005 (Beltratti and Bortolotti, 2006). ${ }^{6}$ Most listed firms are former SOEs, giving rise to severe agency problems. For example, managers have little incentive to enhance the quality of listed firms; and as the primary regulator of the Chinese equity market, the China Securities Regulatory Commission (CSRC) is reluctant to supervise listed firms, although it is concerned with market manipulations and speculations. ${ }^{7}$ Furthermore, the Chinese investor's trading experience and the level of their sophistication is likely to have been less than that of investors in developed markets, and most individual investors in China have short-term investment objectives, in contrast to the longterm focus of foreign investors (Kang et al., 2002; Ng and Wu, 2006 and 2007). These features of Chinese stock markets allows for the poor efficiency of Chinese markets, such as extreme volatility, increased speculation and higher turnover. Therefore, the Chinese stock market provides an interesting setting for asset pricing studies. In such a unique setting, we investigate whether there is a value/growth effect, and whether the superior return of value stocks is a reward for greater investor disagreement about future growth in earnings.

Our study is related to that of Lakonishok, Shleifer and Vishny (1994), who find that value stocks outperform growth stocks in the U.S. setting. They examine the returns on sets of deciles formed from sorts on $\mathrm{B} / \mathrm{M}, \mathrm{E} / \mathrm{P}, \mathrm{C} / \mathrm{P}$, and five-year sales rank. LSV find strong positive relationship between average returns and $\mathrm{B} / \mathrm{M}, \mathrm{E} / \mathrm{P}$, or $\mathrm{C} / \mathrm{P}$, and a negative relationship between average returns and past sales growth. Our study therefore provides out of sample evidence in the Chinese context on the performances of value stocks and growth stocks. Our study is related to Chan et al. (1991) who consider stocks with negative earnings and negative cash flows. Their study also relates cross-sectional differences in returns on Japanese stocks to four fundamental variables, B/M, E/P, C/P and size. Our study is related to Barbee et al. (1996) and Leledakis and Davidson (2001), who document that sales to price is an important indicator of a firm's relative market valuation and is highly significant in explaining cross-sectional stock returns in the US and UK markets. Regarding the relationship between the divergence of opinion and performance of value stocks, our study is related to Doukas et al. (2004) who find

\footnotetext{
Chinese firms are also allowed to issue shares in overseas stock markets, such as H shares listed in the Hong Kong Stock Exchange and N shares listed in the New York Stock Exchange (Poon et al. 1998; Sun and Chong, 2007).

To deal with the problems of non-tradable shares, Chinese authorities made several attempts to release these shares to the public. The first two attempts in 1999 and 2001 failed badly. On 29 April 2005, the Chinese authorities launched a new structural reform program to encourage all A-share listed firms to gradually transform non-tradable shares into tradable shares (Beltratti and Bortolotti, 2006).

Because most controlling shareholders of SOEs are the State-owned Assets Supervision and Administration Commission (SASAC) and the Ministry of Finance (MOF), which are also ministry-level agencies of State Council. To be responsible to the State Council, it is hard for CSRC to enforce independent regulations over listed firms (Li, 2008).
} 
that value stocks are subject to greater investor disagreement than growth stocks and thus earn higher returns. Our study is the first to provide much needed out of sample evidence on whether the superior performance of value stocks is associated with the divergence of opinion among investors.

With regards to the cross-sectional behavior of stock returns to fundamental variables in the Chinese market, our study is related to that of Eun and Huang (2007), who find size and book to market ratio are related to stock returns whereas market risk is not priced; and investors are willing to pay a liquidity premium and value A-shares more if there are offshore counterparts. Our study differs from Eun and Huang (2007) in relating the cross-sectional behavior of stock returns to the range of variables: book-to-market, sales-to-price, earnings-toprice, cash-flow-to-price, leverage and size, and accounting for the explanatory power of investor uncertainty as proxied by their divergence of opinion. The selection of these variables is motivated by many studies in developed markets. We do not, however, consider market risk as an explanatory variable, because prior studies reveal that market beta lacks explanatory power in cross-sectional regressions, even when beta is the only explanatory variable (FF 1992; Wang and Iorio 2007; Eun and Huang 2007).

Our study makes four contributions to the asset pricing literature. First, conducting studies outside of the U.S. contributes to adding out-of-sample evidence by providing a direct test against the data-snooping explanation of Black (1993) and Mackinlay (1995) and the survivorship bias hypothesis of Kothari et al. (1995). Our second contribution is to address that value stocks generate superior returns relative to growth stocks in the Chinese stock market. Our third contribution is that our sample includes stocks with negative earnings and negative cash flows, and our study is the first to evaluate the explanatory power of the sales to price for such stocks. Our fourth contribution is that we investigate how value stocks outperform growth stocks by establishing the link between divergence of opinion and superior performance of value stocks in the Chinese market.

Our findings are as follows. Using data for equities listed in the Shanghai and Shenzhen stock exchanges we find that (1) with the exception of the debt to equity variable, five of the six variables, namely book-to-market, sales-to-price, earnings-to-price, cash-flow-to-price and size, do a good job in simple one-variable classifications of value and growth stocks and show that value stocks outperform growth stocks; (2) we find that that although book to market, sales to price, earnings to price, and cash flow to price are significant in explaining expected returns in the Chinese market, the ratio of cash flow to price has the most significant positive impact on expected returns; however, both size and leverage appear to have insignificant power in explaining returns in the Chinese market; (3) divergence of opinion plays an important role in explaining the superior return of value stocks.

The remainder of the paper is arranged as follows. In the following section, we present the data and methodology employed in the paper. Section 3 presents the findings and Section 4 concludes the paper.

\section{Data and Variable Description}

\section{DATA AND METHODOLOGY}

We obtain monthly stock returns, market capitalization, number of listed shares, the risk-free rate and monthly market returns from the China Stock Market and Accounting Research Database (CSMAR), designed and developed by GTA Information Technology. The risk-free rate is proxied by the monthly return on the one-year fixed deposit and the market return is 
proxied by the monthly value-weighted aggregated market return constructed using A-share stocks listed on the Shanghai and Shenzhen stock exchanges in the CSMAR databases.

We restrict ourselves to investigating the A-share market since the number of B-share listed firms is much less, the B-share market capitalization is much smaller, and the liquidity is much lower than in the A-share market. At the end of 2011, the market capitalization of the A-share stock market was around 20.53 trillion RMB and the total number of A-share stocks was 1988; while the market capitalization of the B-share market was about 0.15 billion RMB, with only 108 listed B-share stocks (CSMAR 2012). Table 1 presents the total number of listed stocks and the market capitalization for the A-share market, annually from January 1995 to December 2011. Accounting data for total shareholders' equity, total liabilities, operating revenue, net profit and net cash flows have also been obtained from the CSMAR Database. Standard deviation in monthly analyst forecasts, the mean of monthly analyst forecasts and the number of analyst forecasts are taken from the Institutional Brokers Estimate System (I/B/E/S).

Table 1

Descriptive statistics of Chinese A-share market for the sample period 1995 to 2011 (Million: Chinese Yuan)

\begin{tabular}{|c|c|c|c|c|c|c|c|c|c|}
\hline & \multicolumn{3}{|c|}{ Shanghai A-share market } & \multicolumn{3}{|c|}{ Shenzhen A-share market } & \multicolumn{3}{|c|}{ Combined A-share market } \\
\hline Year & $\begin{array}{c}\text { MV of } \\
\text { Tradable } \\
\text { shares }\end{array}$ & Total MV & $\begin{array}{l}\text { Number } \\
\text { of listed } \\
\text { stocks }\end{array}$ & $\begin{array}{c}\text { MV of } \\
\text { Tradable } \\
\text { shares }\end{array}$ & $\begin{array}{c}\text { Total } \\
\text { MV }\end{array}$ & $\begin{array}{c}\text { Number } \\
\text { of } \\
\text { listed } \\
\text { stocks }\end{array}$ & $\begin{array}{c}\text { MV of } \\
\text { Tradable } \\
\text { shares }\end{array}$ & Total MV & $\begin{array}{c}\text { Number } \\
\text { of } \\
\text { listed } \\
\text { stocks }\end{array}$ \\
\hline 1995 & 49.82 & 244.64 & 169 & 29.86 & 89.14 & 118 & 79.68 & 333.78 & 287 \\
\hline 1996 & 125.36 & 534.12 & 184 & 126.84 & 418.75 & 127 & 252.20 & 952.87 & 311 \\
\hline 1997 & 235.21 & 912.45 & 287 & 252.97 & 819.21 & 227 & 488.18 & $1,731.66$ & 514 \\
\hline 1998 & 287.27 & 1060.21 & 372 & 267.51 & 873.93 & 347 & 554.78 & $1,934.15$ & 719 \\
\hline 1999 & 412.4 & 1448.99 & 425 & 385.34 & 1181.53 & 400 & 797.74 & $2,630.52$ & 825 \\
\hline 2000 & 819.47 & 2674.72 & 471 & 735.59 & 2105.29 & 452 & $1,555.06$ & $4,780.02$ & 923 \\
\hline 2001 & 771.92 & 2710.87 & 559 & 560.89 & 1543.79 & 501 & $1,332.81$ & $4,254.66$ & 1060 \\
\hline 2002 & 704.57 & 2497.78 & 635 & 472.48 & 1270.68 & 500 & $1,177.06$ & $3,768.46$ & 1135 \\
\hline 2003 & 783.93 & 2947.91 & 704 & 452.43 & 1220.31 & 494 & $1,236.36$ & $4,168.22$ & 1198 \\
\hline 2004 & 707.14 & 2577.18 & 770 & 399.5 & 1076.84 & 492 & $1,106.64$ & $3,654.02$ & 1262 \\
\hline 2005 & 652.39 & 2287.70 & 826 & 350.89 & 896.97 & 524 & $1,003.28$ & $3,184.68$ & 1350 \\
\hline 2006 & 1592.72 & 7135.89 & 822 & 791.95 & 1755.68 & 530 & $2,384.67$ & $8,891.57$ & 1352 \\
\hline 2007 & 6343.81 & 26931.56 & 827 & 2738.02 & 5624.68 & 563 & $9,081.83$ & $32,556.24$ & 1390 \\
\hline 2008 & 3122.98 & 9565.38 & 844 & 1233.99 & 2349.69 & 715 & $4,458.56$ & $14,824.85$ & 1559 \\
\hline 2009 & 11381.78 & 18393.19 & 850 & 3519.65 & 5692.27 & 776 & 14901.43 & 21912.84 & 1626 \\
\hline 2010 & 14104.05 & 17862.18 & 866 & 4709.93 & 7709.87 & 971 & 18813.98 & 22572.11 & 1837 \\
\hline 2011 & 12171.06 & 14784.89 & 904 & 3816.65 & 5746.71 & 1084 & 15987.71 & 18601.54 & 1988 \\
\hline
\end{tabular}

This table reports the development of the Chinese A-share markets. Market value of tradable shares, total market value, and the number of listed stocks are obtained from the China Stock Market and Accounting Research (CSMAR) Database

The test period is 1995 to 2011. There are two main reasons for commencing the sample in January 1995. First, the number of listed stocks is quite small prior to 1995. Second, the Company Law that became effective in 1994 standardized the information disclosure of listed companies, so that accounting statements of listed companies are more structured and comparable from $1995 .^{8}$

On November 30,1992, with the approval of the State Council, the Minister of Finance signed and issued the first set of a`1`11 121 1ccounting standards for China - "Accounting Standard for Business Enterprises". All business enterprises were required to comply with the standards beginning July 1, 1993. In an attempt to standardize the format of statements, the CRSC released "Regulation Number Two on Information Disclosure by Listed Companies 
Following, Eun and Huang (2007), we define book equity as the total shareholders' equity, debt as total liabilities, sales as operating revenue, earnings as net profit and cash flow as net cash flow from operating activities. For calculating accounting ratios, size is defined as the market value of total outstanding shares (tradable and non-tradable shares), and for the portfolio and regression analyses, is defined as the market value of tradable shares. In contrast with Eun and Huang (2007) and FF (1992), who measure the fundamental variables on an annual basis, we follow Chan et al. (1991) in the regressions and measure fundamental variables on a monthly basis in relation to moving stock prices. Following both Eun and Huang (2007) and Wang and Di Iorio (2007) who find that beta lacks explanatory power in cross-sectional regressions for China stocks, we do not consider beta as a proxy for market risk in our analysis.

To be consistent with prior studies, several data filters are applied. First, the accounting data are matched with the corresponding trading data. To this end, we restrict our sample to those firms that have a valid monthly return and market capitalization, as well as accounting data on total shareholders' equity, total liabilities, earnings, cash flows and operating revenues at the end of the previous year. This filter eliminates approximately $5.77 \%$ of the initial observations. Second, firms that have negative book value of equity are excluded from the final sample (around $1.51 \%$ of the sample). However, stocks with negative earnings or negative cash flows are retained in our sample. ${ }^{9}$ Together, our filters eliminate 17,409 observations, so that our final sample comprises 2,392 stocks producing 221,443 monthly observations.

In order to test whether the performance of value stocks is related to investor uncertainty about a stock's future prospects, dispersion in analyst forecasts is employed as a proxy for investors' divergence of opinion. We follow Diether et al. (2002) and define dispersion as the ratio of the standard deviation of analysts' current-fiscal-year annual earnings per share forecasts to the absolute value of the mean forecast, as reported in the I/B/E/S Summary History File. Following, prior research (Diether et al. 2002; Doukas et al. 2004), we require that a stock must have a minimum of two analyst forecasts in a month to be included in the sample. ${ }^{10}$ We use analysts' forecasts issued in June, as well as analysts' forecasts issued in April or May as confirmed in June. Since many firms listed on CSMAR are not covered by I/B/E/S, the useable sample declines appreciably. The sample at this stage comprises 1,224 stocks with 33,635 observations.

\section{METHODOLOGY}

Listed firms in China have a fiscal year-end on 31 December, and generally release their financial statements within 120 days of the year end. To avoid any concerns of a look-ahead bias, we ensure that the accounting information is feasibly available to all investors on a yearby-year basis. The analysis of the performances of value and growth stocks is conducted at the portfolio level. At the end of each month from January 1995 to December 2011, stocks with positive values of $\mathrm{B} / \mathrm{M}, \mathrm{S} / \mathrm{P}, \mathrm{D} / \mathrm{E}, \mathrm{E}(+) / \mathrm{P}$, and $\mathrm{C}(+) / \mathrm{P}$ are allocated into five quintiles, and the remaining stocks with negative E/P (E/P DUMMY) and negative C/P(C/P DUMMY) are also placed into five quintiles. Quintile 1 ('growth' portfolio) contains stocks with the lowest values

in 1994 - The Contents and Formats of Annual Reports" (Draft), which stipulated the contents, format and timing of declaration of annual reports.

Approximately, 11\% (23\%) of the monthly observations involve negative earnings (negative cash flows). 10 From the I/B/E/S Summery File, the number of firms listed in Chinese A-share market that have analyst forecasts is 1655; the number of firms which have only one analyst forecast is 431 ; and the number of firms which have at least two analyst forecasts is 1,224 . 
of the chosen variable $(\mathrm{B} / \mathrm{M}, \mathrm{S} / \mathrm{P}, \mathrm{D} / \mathrm{E}, \mathrm{E}(+) / \mathrm{P}$, or $\mathrm{C}(+) / \mathrm{P})$, while Quintile 5 ('value' portfolio) contains stocks with the highest values of each, respectively. Similarly, the most negative E/P (C/P) firms are placed in Qunitile 1 and the least negative E/P (C/P) firms are placed in Quintile 5. The equal-weighted monthly average returns and the average values of the remaining characteristic variables of each portfolio are then calculated.

Our motivation for including stocks that have either negative earnings or negative cash flows stems from FF (1992) who document that average returns for negative earnings firms are actually quite high, being similar to the average returns of high earnings-to-price (E/P) firms. In a similar vein, Chan et al. (1991) find that stocks with negative fundamental values are likely to earn relatively high returns.

Similar to Chan et al. (1991) and FF (1992), we perform both univariate and multivariate regressions at the individual stock level. We use subsequent monthly returns as a proxy for expected returns. Thus, at the end of each month $t$, individual stock returns in month $t+1$ are regressed on the fundamental variables, $\mathrm{B} / \mathrm{M}, \mathrm{S} / \mathrm{P}, \mathrm{D} / \mathrm{E}, \mathrm{E} / \mathrm{P}, \mathrm{C} / \mathrm{P}$ and size, as measured in month $t$. Our cross-sectional model is as follows:

$$
\begin{aligned}
R_{i}=\beta_{0}+\beta_{1} \ln (B / M)+\beta_{2} \ln (S / P)+\beta_{3} \ln (D / E)+\beta_{4} \ln E(+) / P+ \\
D N E^{*} \beta_{5} \ln E(-) / P+\beta_{6} \ln C(+) / P+D N C^{*} \beta_{7} \ln C(-) / P+\beta_{8} \ln (M E)+\varepsilon_{i}
\end{aligned}
$$

where if earnings are positive, $\mathrm{E}(+) / \mathrm{P}$ is the ratio of total earnings to total market value of outstanding shares and the dummy variable DNE is zero; if earnings are negative, $\mathrm{E}(+) / \mathrm{P}$ is zero and the dummy variable DNE is one. If cash flows are positive, the dummy variable DNC is zero; if cash flows are negative, $\mathrm{C}(+) / \mathrm{P}$ is zero and the dummy variable $\mathrm{DNC}$ is one.

At the end of June of each year $t$ (1995-2011), all stocks that have at least two analyst forecasts are sorted into three equal groups based on the market value of their tradable shares. Stocks are also independently allocated to three equal groups based on book-to-market ratio. The nine size-B/M portfolios are the intersections of the three size and the three B/M groups. The time-series mean and median values of dispersion for the portfolios are calculated from July of year $t$ to June of year $t+1$.

To examine the robustness of the relationship between the divergence of opinion and average stock returns, we construct an asset-pricing model for portfolios based on Carhart's (1997) four-factor model with a disagreement risk factor (DRF). We follow FF (1993) and Carhart (1997) in constructing the zero-cost portfolios: We define SMB as the difference in average returns between small-stock portfolios $(\mathrm{S} / \mathrm{L}, \mathrm{S} / \mathrm{M}$ and $\mathrm{S} / \mathrm{H})$ and big-stock portfolios $(\mathrm{B} / \mathrm{L}, \mathrm{B} / \mathrm{M}$ and $\mathrm{B} / \mathrm{H})$; $\mathrm{HML}$ is the difference in average returns between high $\mathrm{B} / \mathrm{M}$ portfolios $(\mathrm{S} / \mathrm{H}, \mathrm{B} / \mathrm{H})$ and low $\mathrm{B} / \mathrm{M}$ portfolios $(\mathrm{S} / \mathrm{L}, \mathrm{B} / \mathrm{L}) ; \mathrm{MOM}$ is the difference in average returns between the 30 percent of firms with the highest eleven-month returns lagged one month, and the 30 percent of firms with the lowest eleven-month returns lagged one month; and DRF is the difference in average returns between the 30 percent of firms with the highest divergence of opinion and the 30 percent of firms with the lowest divergence of opinion. Our five-factor model can be shown as follows.

$$
R_{p t}-R_{f t}=a_{p t}+b_{p}\left(R_{M t}-R_{f t}\right)+s_{p} S M B_{t}+h_{p} H M L_{t}+m_{p} M O M_{t}+d_{p} D R F_{t}+\varepsilon_{p t}
$$

where $\left(R_{p t}-R_{f t}\right)$ is the excess monthly return of the test portfolio, $\left(R_{M t}-R_{f t}\right)$ is the excess monthly return of the market portfolio, $\mathrm{SMB}_{t}, \mathrm{HML}_{t}, \mathrm{MOM}_{t}$, and $\mathrm{DRF}_{t}$ are the monthly returns on the zero-cost portfolio based on size, book-to-market, prior one year momentum, and divergence of opinion, respectively. In addition, we follow MacKinlay and Richardson (1991), 
Faff (2001), Gharghori et al (2011) and employ the Generalized Method of Moments (GMM) approach in a system-based application to perform the asset pricing tests.

There are two principal reasons for employing the system-based regression analysis (general method of moments, GMM). First, as Gharghori et al. (2011) point, this approach allows us to concurrently estimate the factor premiums of each explanatory variable. That is, we can test for significance of the premia for the specified factors: $\mathrm{H}_{0}: \lambda_{\mathrm{m}}=0 ; \mathrm{H}_{0}: \lambda_{\mathrm{SMB}}=0 ; \mathrm{H}_{0}: \lambda_{\mathrm{HML}}=0 ; \mathrm{H}_{0}$ : $\lambda_{\mathrm{MOM}}=0$; and $\mathrm{H}_{0}: \lambda_{\mathrm{DRF}}=0$. Recall that Doukas et al. (2004) document that the factor premium of DRF is positive and significant, whereas Diether et al. (2002) document that the factor premium of DRF is negative and significant. The main advantage of the GMM approach is that it permits us to directly test which of the conflicting findings of Doukas et al. (2004) and Diether et al. (2002) is supported. The second advantage of this approach is that it allows us to perform regressions for all portfolios simultaneously (Gharghori et al 2011). The divergence of opinion enhanced Carhart (1997) model can be shown as:

$$
E\left(R_{p}\right)-R_{f}=b_{p}\left[E\left(R_{m}\right)-R_{f}\right]+s_{p} E(S M B)+h_{p} E(H M L)+m_{p} E(M O M)+d_{p} E(D R F)
$$

We can augment the system to allow a direct estimation of the premia for the five risk factors:

$$
\begin{aligned}
& r_{p t}=b_{p} r_{m t}+s_{p} S M B_{t}+h_{p} H M L_{t}+m_{p} M O M_{t}+d_{p} D R F_{t}+\varepsilon_{p t} \\
& r_{m t}=\lambda_{m t}+\xi_{b t} \\
& S M B_{t}=\lambda_{S M B}+\xi_{s t} \\
& H M L_{t}=\lambda_{H M L}+\xi_{h t} \\
& M O M_{t}=\lambda_{M O M}+\xi_{m t} \\
& D R F_{t}=\lambda_{D R F}+\xi_{d t}
\end{aligned}
$$

The role of the divergence of opinion augmented Carhart model is tested based on the above system. Equations (5), (6), (7), (8) and (9) effectively impose a mean adjusted transformation to the independent variables of equation (4). Here, the null hypothesis is a test of whether the intercept term (a) is equal to a non-zero restriction.

$$
H_{0}: a=b_{p} \lambda_{m}+s_{p} \lambda_{S M B}+h_{p} \lambda_{H M L}+m_{p} \lambda_{M O M}+d_{p} \lambda_{D R F}
$$

We follow Connor and Korajczyk (1988) and Faff (1992) and employ the Modified Likelihood Ratio Test (MLRT) to determine whether DRF is useful in our asset-pricing tests. That is, we test whether the coefficients on DRF are jointly equal to zero. If the null is not rejected, DRF has no ability to price the test portfolios; otherwise, DRF is useful in pricing the test portfolios.

\section{Preliminary Results}

\section{EMPIRICAL RESULTS}

In Table 2, we present average monthly returns and characteristics for the period January 1995 to December 2011 on portfolios sorted on each of the firm characteristics (B/M, S/P, D/E, $\mathrm{E} / \mathrm{P}, \mathrm{C} / \mathrm{P}$ and size). In each panel, stocks are assigned to portfolios as described in the prior section. 
Table 2

Returns and firm characteristics for portfolios sorted by each of the variables

\begin{tabular}{lrrrrr}
\hline \multicolumn{1}{l}{ Panel A: B/M } & \multicolumn{1}{c}{$\mathrm{Q}_{2}$} & \multicolumn{1}{c}{$\mathrm{Q}_{3}$} & \multicolumn{1}{c}{$\mathrm{Q}_{4}$} & \multicolumn{1}{c}{$\mathrm{Q}_{5}$} \\
\hline Return & 0.0110 & 0.0147 & 0.0171 & 0.0207 & 0.0223 \\
B/M & 0.0976 & 0.2471 & 0.3333 & 0.4361 & 0.6739 \\
S/P & 0.2492 & 0.3439 & 0.4417 & 0.5513 & 0.8096 \\
D/E & 0.3241 & 0.3176 & 0.3622 & 0.4611 & 0.8846 \\
Size & $2.25 \mathrm{E}+09$ & $2.05 \mathrm{E}+09$ & $1.91 \mathrm{E}+09$ & $2.14 \mathrm{E}+09$ & $4.18 \mathrm{E}+09$ \\
E/P & -0.0192 & 0.0166 & 0.0219 & 0.0263 & 0.0338 \\
C/P & 0.0144 & 0.0249 & 0.0284 & 0.0382 & 0.0692 \\
\hline
\end{tabular}

\begin{tabular}{lrrrrr}
\hline Panel B: S/P & \multicolumn{1}{c}{} \\
\hline & \multicolumn{1}{c}{$\mathrm{Q}_{1}$} & \multicolumn{1}{c}{$\mathrm{Q}_{2}$} & \multicolumn{1}{c}{$\mathrm{Q}_{3}$} & \multicolumn{1}{c}{$\mathrm{Q}_{4}$} & \multicolumn{1}{c}{$\mathrm{Q}_{5}$} \\
\hline Return & 0.0131 & 0.0158 & 0.0165 & 0.0187 & 0.0217 \\
B/M & 0.2231 & 0.2964 & 0.3581 & 0.4082 & 0.5040 \\
S/P & 0.0818 & 0.1903 & 0.3166 & 0.5221 & 1.2860 \\
D/E & 0.2568 & 0.3181 & 0.3837 & 0.4910 & 0.8995 \\
Size & $2.35 \mathrm{E}+09$ & $2.14 \mathrm{E}+09$ & $2.63 \mathrm{E}+09$ & $2.35 \mathrm{E}+09$ & $3.07 \mathrm{E}+09$ \\
E/P & -0.0001 & 0.0153 & 0.0196 & 0.0192 & 0.0266 \\
C/P & 0.0124 & 0.0220 & 0.0308 & 0.0409 & 0.0692 \\
\hline
\end{tabular}

\begin{tabular}{|c|c|c|c|c|c|}
\hline \multicolumn{6}{|c|}{ Panel C: D/E } \\
\hline & $Q_{1}$ & $\mathrm{Q}_{2}$ & $\mathrm{Q}_{3}$ & $\mathrm{Q}_{4}$ & $Q_{5}$ \\
\hline Return & 0.0133 & 0.0155 & 0.0174 & 0.0190 & 0.0206 \\
\hline $\mathrm{B} / \mathrm{M}$ & 0.2618 & 0.3081 & 0.3483 & 0.4020 & 0.4678 \\
\hline $\mathrm{S} / \mathrm{P}$ & 0.1814 & 0.3043 & 0.4066 & 0.5629 & 0.9411 \\
\hline $\mathrm{D} / \mathrm{E}$ & 0.0740 & 0.1758 & 0.2967 & 0.4846 & 1.3187 \\
\hline Size & $1.93 E+09$ & $1.83 E+09$ & $2 E+09$ & $2.33 E+09$ & $4.44 E+09$ \\
\hline$E / P$ & 0.0226 & 0.0240 & 0.0224 & 0.0195 & -0.0084 \\
\hline $\mathrm{C} / \mathrm{P}$ & 0.0212 & 0.0257 & 0.0315 & 0.0369 & 0.0598 \\
\hline \multicolumn{6}{|c|}{ Panel D: Size } \\
\hline & $\mathrm{Q}_{1}$ & $\mathrm{Q}_{2}$ & $\mathrm{Q}_{3}$ & $\mathrm{Q}_{4}$ & $Q_{5}$ \\
\hline Return & 0.0225 & 0.0192 & 0.0160 & 0.0145 & 0.0131 \\
\hline $\mathrm{B} / \mathrm{M}$ & 0.2814 & 0.3576 & 0.3833 & 0.3833 & 0.3788 \\
\hline $\mathrm{S} / \mathrm{P}$ & 0.3994 & 0.4578 & 0.5012 & 0.5118 & 0.5179 \\
\hline $\mathrm{D} / \mathrm{E}$ & 0.4254 & 0.4051 & 0.4173 & 0.4148 & 0.6723 \\
\hline Size & $3.92 \mathrm{E}+08$ & $6.98 E+08$ & $1.06 \mathrm{E}+09$ & $1.75 E+09$ & $8.3 E+09$ \\
\hline $\mathrm{E} / \mathrm{P}$ & -0.0189 & 0.0100 & 0.0195 & 0.0277 & 0.0406 \\
\hline $\mathrm{C} / \mathrm{P}$ & 0.0119 & 0.0256 & 0.0340 & 0.0399 & 0.0622 \\
\hline
\end{tabular}


Table 2 -continued

\begin{tabular}{|c|c|c|c|c|c|c|c|c|c|c|}
\hline \multicolumn{11}{|c|}{ Panel F: C/P } \\
\hline $\begin{array}{l}\text { C/P } \\
\text { DUMMY } \\
\text { C/P+ }\end{array}$ & $\mathrm{Q}_{1}$ & $\mathrm{Q}_{2}$ & $\mathrm{Q}_{3}$ & $\mathrm{Q}_{4}$ & $\mathrm{Q}_{5}$ & $\mathrm{Q}_{1}$ & $\mathrm{Q}_{2}$ & $\mathrm{Q}_{3}$ & $\mathrm{Q}_{4}$ & $\mathrm{Q}_{5}$ \\
\hline Return & 0.0249 & 0.0213 & 0.0198 & 0.0158 & 0.0146 & 0.0139 & 0.0133 & 0.0173 & 0.0185 & 0.0229 \\
\hline $\mathrm{B} / \mathrm{M}$ & 0.1037 & 0.3234 & 0.2921 & 0.3083 & 0.3037 & 0.3168 & 0.3122 & 0.3329 & 0.3840 & 0.5014 \\
\hline S/P & 0.6282 & 0.4062 & 0.3664 & 0.3110 & 0.3200 & 0.3510 & 0.3762 & 0.4130 & 0.5197 & 0.7777 \\
\hline$D / E$ & 1.2657 & 0.7085 & 0.5538 & 0.4400 & 0.3835 & 0.3641 & 0.3374 & 0.3368 & 0.4284 & 0.7682 \\
\hline Size & $1.06 \mathrm{E}+09$ & $1.02 \mathrm{E}+09$ & $1.12 \mathrm{E}+09$ & $9.4 \mathrm{E}+08$ & $1.25 \mathrm{E}+09$ & $1.37 \mathrm{E}+09$ & $1.66 \mathrm{E}+09$ & $1.88 \mathrm{E}+09$ & $2.49 \mathrm{E}+09$ & $5.94 \mathrm{E}+09$ \\
\hline $\mathrm{E} / \mathrm{P}$ & -0.3690 & -0.1091 & -0.0609 & -0.0305 & -0.0093 & 0.0073 & 0.0181 & 0.0271 & 0.0380 & 0.0695 \\
\hline $\mathrm{C} / \mathrm{P}$ & -0.0235 & 0.0011 & 0.0030 & 0.0103 & 0.0063 & 0.0206 & 0.0244 & 0.0297 & 0.0406 & 0.0849 \\
\hline
\end{tabular}

Panel F: C/P

$\mathrm{C} / \mathrm{P}$

$\begin{array}{llllll}\text { DUMMY } & Q_{1} & Q_{2} & Q_{3} & Q_{4} & Q_{5}\end{array}$

\begin{tabular}{lllllllllll} 
C/P+ & & & & & & \multicolumn{1}{c}{$\mathrm{Q}_{1}$} & \multicolumn{1}{c}{$\mathrm{Q}_{2}$} & \multicolumn{1}{c}{$\mathrm{Q}_{3}$} & \multicolumn{1}{c}{$\mathrm{Q}_{4}$} & $\mathrm{Q}_{5}$ \\
\hline Return & 0.0147 & 0.0135 & 0.0143 & 0.0112 & 0.0115 & 0.0110 & 0.0135 & 0.0146 & 0.0161 & 0.0190 \\
B/M & 0.3888 & 0.3617 & 0.3222 & 0.2793 & 0.2081 & 0.2630 & 0.3048 & 0.3418 & 0.3937 & 0.5143 \\
S/P & 0.7492 & 0.5082 & 0.4679 & 0.3609 & 0.2993 & 0.3199 & 0.3519 & 0.4304 & 0.5695 & 0.9008 \\
D/E & 0.9727 & 0.5393 & 0.4547 & 0.3771 & 0.3603 & 0.2823 & 0.2967 & 0.3384 & 0.4592 & 1.0965 \\
Size & $4.09 \mathrm{E}+09$ & $2.01 \mathrm{E}+09$ & $1.82 \mathrm{E}+09$ & $1.63 \mathrm{E}+09$ & $1.61 \mathrm{E}+09$ & $1.99 \mathrm{E}+09$ & $2.24 \mathrm{E}+09$ & $2.48 \mathrm{E}+09$ & $2.82 \mathrm{E}+09$ & $7.46 \mathrm{E}+09$ \\
E/P & -0.0466 & -0.0197 & -0.0156 & -0.0168 & -0.0205 & 0.0048 & 0.0129 & 0.0171 & 0.0227 & 0.0382 \\
C/P & -0.1635 & -0.0544 & -0.0274 & -0.0130 & -0.0038 & 0.0077 & 0.0227 & 0.0400 & 0.0661 & 0.1634 \\
\hline
\end{tabular}

This table presents the average monthly returns and firm characteristics for portfolios sorted by B/M, S/P, D/E, size, E/P, and C/P for both Shanghai and Shenzhen A-share stocks from April 1995 to December 2011. At the end of each month, five portfolios of equal number of stocks are formed on positive values of the variables with five special quintiles formed for stocks with negative earnings or negative cash flows. $\mathrm{B} / \mathrm{M}$ is the ratio of book value of equity to market value of equity; $\mathrm{S} / \mathrm{P}$ is the ratio of operating revenues to market value of equity; $\mathrm{D} / \mathrm{E}$ is leverage-debt to equity ratio; size refers to market value of tradable A shares (millions of yuan); $\mathrm{E} / \mathrm{P}$ is the ratio of earnings to market value of equity; and $\mathrm{C} / \mathrm{P}$ is the ratio of cash flow to market value of equity. The market equity used to measure these accounting ratios is the market value of total outstanding shares at the end of each month in year $t$.

Panels A, B, C and D report the monthly returns and explanatory variables on quintile portfolios sorted on B/M, S/P, D/E and Size, respectively. Panels E and F report the monthly returns on quintile portfolios based on $\mathrm{E}(+) / \mathrm{P}$ and $\mathrm{C}(+) / \mathrm{P}$ and on $\mathrm{E} / \mathrm{P}$ DUMMY and $\mathrm{C} / \mathrm{P}$ DUMMY. For $\mathrm{E}(+) / \mathrm{P}$ and $\mathrm{C}(+) / \mathrm{P}, \mathrm{Q}_{1}$ contain stocks with the lowest positive values $(\mathrm{B} / \mathrm{M}, \mathrm{S} / \mathrm{P}$, $\mathrm{D} / \mathrm{E}$, size, $\mathrm{E} / \mathrm{P}$, and $\mathrm{C} / \mathrm{P})$; $\mathrm{Q}_{5}$ contain stocks with the highest positive values $(\mathrm{B} / \mathrm{M}, \mathrm{S} / \mathrm{P}, \mathrm{D} / \mathrm{E}$, size, $\mathrm{E} / \mathrm{P}$, and $\mathrm{C} / \mathrm{P}$ ); and stocks with negative earnings or negative cash flow are also placed in five groups. $\mathrm{Q}_{1}$ consists of most negative $\mathrm{E} / \mathrm{P}$ or $\mathrm{C} / \mathrm{P}$ stocks, while $\mathrm{Q}_{5}$ consists of least negative $\mathrm{E} / \mathrm{P}$ or $\mathrm{C} / \mathrm{P}$ stocks.

Panel A of Table 2 presents the monthly returns and characteristics for portfolios formed on $\mathrm{B} / \mathrm{M}$. Panel A reveals a positive $\mathrm{B} / \mathrm{M}$ effect: on average, the lowest $\mathrm{B} / \mathrm{M}$ quintile $\left(\mathrm{Q}_{1}\right)$ has a return of $1.10 \%$ per month, while the highest $B / M$ quintile $\left(Q_{5}\right)$ has a return of $2.23 \%$ per month, a difference of $1.13 \%\left(Q_{5}-Q_{1}\right)$ per month. This is consistent with the findings for developed markets (Japan: Chan et al., 1991; US: FF, 1992, 1998; LSV, 1994; Australia: Chan and Faff, 2003) and prior findings for China (Eun and Huang, 2007). Interestingly, we also observe a monotonic increase in the average $\mathrm{S} / \mathrm{P}, \mathrm{E} / \mathrm{P}$ and $\mathrm{C} / \mathrm{P}$ values across the $\mathrm{B} / \mathrm{M}$ portfolios. 
In Panel B of Table 2, we present the results for sorting on the ratio of $\mathrm{S} / \mathrm{P}$. The table shows a positive and monotonic relationship between $\mathrm{S} / \mathrm{P}$ and average returns: the lowest quintile $\left(\mathrm{Q}_{1}\right)$ generates a return of $1.31 \%$, whereas the highest quintile $\left(Q_{5}\right)$ has a return of $2.17 \%$, a difference of $0.86 \%$ per month. This result is consistent with findings reported by Barbee, Mukherji and Raines (1996) and Leledakis and Davidson (2001). The average B/M, E/P and $\mathrm{C} / \mathrm{P}$ values increase monotonically across $\mathrm{S} / \mathrm{P}$ portfolios.

Panel $\mathrm{C}$ of Table 2 presents the results for the debt-to-equity ratio. The returns range from $1.33 \%$ per month for the lowest D/E portfolio (Q1) to $2.06 \%$ per month for the highest D/E portfolio (Q5), a difference of $0.73 \%$ per month. The spread in returns is similar compared with either $\mathrm{B} / \mathrm{M}$ or $\mathrm{S} / \mathrm{P}$. In addition, the panel reveals a monotonic increase for $\mathrm{S} / \mathrm{P} \mathrm{E} / \mathrm{P}$ and $\mathrm{C} / \mathrm{P}$ across the quintile portfolios.

Panel D of Table 2 reveals a strong negative relationship between average returns and size: the portfolio of smallest firms $\left(Q_{1}\right)$ earns an average return of $2.25 \%$ per month and the portfolio of largest firms $\left(Q_{5}\right)$ earns an average return of $1.31 \%$ per month, a difference of $0.94 \%$ per month. This negative relationship between average returns and firm size is consistent with many studies including Banz (1981), Fama and French $(1992,1993)$, Chan and Faff (2003) and Eun and Huang (2007). There is also a positive monotonic increase in E/P and C/P across the Size portfolios.

Panel E of Table 2 presents the average returns for portfolios formed on both positive (E(+)/P) and negative (E/P DUMMY) earnings-per-share. Consistent with LSV (1994), we find a positive relationship between average returns and $\mathrm{E}(+) / \mathrm{P}$ with average returns increasing from $1.39 \%$ per month for the lowest quintile of positive E/P stocks $\left(Q_{1}\right)$ to $2.29 \%$ per month for the highest quintile $\left(\mathrm{Q}_{5}\right)$, a difference of $0.90 \%$ per month. For the stocks with negative earnings (E/P DUMMY), the relatively high return of $2.49 \%$ is generated by most negative E/P stocks $\left(\mathrm{Q}_{1}\right)$, while stocks with the least $\mathrm{E} / \mathrm{P}$ have average return of $1.46 \%\left(\mathrm{Q}_{5}\right)$, a difference of $1.03 \%$. It is worth noting that on average E/P DUMMY stocks relatively outperform E/P(+) stocks, consistent with Chan et al. (1991).

Panel $\mathrm{F}$ of Table 2 presents the results for portfolios formed on both positive $(\mathrm{C}(+) / \mathrm{P})$ and negative (C/P DUMMY) cash-flow-to price. We observe a positive relationship between average returns and $\mathrm{C}(+) / \mathrm{P}$. The lowest quintile of positive $\mathrm{C} / \mathrm{P}$ stocks has an average monthly return of $1.10 \%$, and the highest quintile an average monthly return of $1.90 \%$, a difference of $0.80 \%$ per month. We note here that low C/P DUMMY stocks have superior returns relative to high C/P DUMMY stocks with a difference of $0.32 \%\left(Q_{1}-Q_{5}\right)$, which is smaller than the spread in portfolio returns based on E/P DUMMY. Overall, our findings indicate that value stocks have outperformed growth stocks in China.

\section{Cross-Sectional Regression Results}

\section{Univariate Fama-MacBeth Regressions}

Based on the definitions of value stocks and growth stocks, we conduct Fama-MacBeth (FM) regression analysis to investigate the relationship between fundamental variables and stock returns. Table 3 shows time-series averages of the slopes from the month-by-month FamaMacBeth (FM) regressions of the cross-section of stock returns on $B / M, S / P$, leverage, size, $\mathrm{E}(+) / \mathrm{P}, \mathrm{E} / \mathrm{P}$ DUMMY, $\mathrm{C}(+) / \mathrm{P}$ and $\mathrm{C} / \mathrm{P}$ DUMMY. The average slopes and $t$-statistics test the independent ability of each of the fundamental variables to explain stock returns during the period 1995-2011. 
Table 3

Univariate Fama-MacBeth regressions of returns on each of the six variables over the period 1995-2011

\begin{tabular}{|c|c|c|c|c|c|c|}
\hline & Const & Variable & $\mathrm{E}(+) / \mathrm{P}$ & E/P DUMMY & $\mathrm{C}(+) / \mathrm{P}$ & C/P DUMMY \\
\hline \multirow[t]{2}{*}{$\mathrm{B} / \mathrm{M}$} & 0.0094 & 0.0054 & & & & \\
\hline & $(1.66)$ & $(3.46)$ & & & & \\
\hline \multirow[t]{2}{*}{$\mathrm{S} / \mathrm{P}$} & 0.0098 & 0.0045 & & & & \\
\hline & $(1.30)$ & $(4.49)$ & & & & \\
\hline \multirow[t]{2}{*}{$\mathrm{D} / \mathrm{E}$} & 0.0091 & 0.0033 & & & & \\
\hline & $(1.24)$ & (2.39) & & & & \\
\hline \multirow[t]{2}{*}{ Size } & 0.0070 & -0.0062 & & & & \\
\hline & $(2.67)$ & $(-2.55)$ & & & & \\
\hline \multirow[t]{2}{*}{$\mathrm{E} / \mathrm{P}$} & 0.0047 & & 0.0030 & 0.0022 & & \\
\hline & (1.59) & & (2.81) & (1.72) & & \\
\hline $\mathrm{C} / \mathrm{P}$ & $\begin{array}{l}0.0063 \\
(1.33)\end{array}$ & & & & $\begin{array}{l}0.0036 \\
(3.20)\end{array}$ & $\begin{array}{l}0.0038 \\
(3.01)\end{array}$ \\
\hline
\end{tabular}

This table reports the average slopes from month-by-month cross-sectional regressions by using individual stock data. The sample period is from January 1995 to December 2011. The corresponding $t$-statistics are reported in parentheses. In the OLS regressions, the monthly excess returns of individual stocks in the subsequent month are regressed on each of the explanatory variables. All explanatory variables are log-transformed variables. Thus, B/M is the natural logarithm of the book to market ratio; $\mathrm{D} / \mathrm{E}$ is the natural logarithm of the debt to equity ratio; $\mathrm{S} / \mathrm{P}$ is the natural logarithm of the sales to price ratio; size is the natural logarithm of the market value of tradable shares; $\mathrm{E}(+) / \mathrm{P}$ is the natural logarithm of positive earnings-toprice ratios; E/P DUMMY is the natural logarithm of the absolute value of negative earnings to price ratios; $\mathrm{C}(+) / \mathrm{P}$ is the natural logarithm of positive cash flow to price ratio; and $\mathrm{C} / \mathrm{P}$ DUMMY is the natural logarithm of the absolute value of negative cash flow to price ratio, The average slope is the time-series average of the monthly regression slopes for January 1995 to December 2011, and the $t$-statistic is the average slope divided by its time-series standard error.

Consistent with Table 2, the regressions in Table 3 suggest that $\mathrm{B} / \mathrm{M}$ and S/P individually contributes to the explanation of average stock returns ( $t$-statistics 3.46 and 4.49, respectively); and show that $\mathrm{D} / \mathrm{E}$ also has significant explanatory power in explaining stock returns in the Chinese market (average slope 0.0033 , with a $t$-statistic of 2.39). For the regression of returns on the size variable, the average slope is -0.0062 with a $t$-statistic of 2.55 .

Consistent with the findings of Eun and Huang (2007), we uncover a positive and significant relationship between average returns and positive earnings-to-price $(E(+) / P)$ (average slope 0.0030 , with $t$-statistic 2.81), as well as an insignificant coefficient on negative earnings-toprice (E/P DUMMY) ( $t$-statistic 1.72). To further investigate the explanatory power of $E / P$, we run univariate regressions of returns separately on $\mathrm{E}(+) / \mathrm{P}$ and $\mathrm{E} / \mathrm{P}$ DUMMY. In unreported results, we find that $\mathrm{E}(+) / \mathrm{P}$ is again significant ( $t$-statistic 2.95), and $\mathrm{E} / \mathrm{P}$ DUMMY again insignificant ( $t$-statistic 1,98). We run regressions similarly for $\mathrm{C} / \mathrm{P}$. The results in Table 3 show that the coefficients are positive and significant for both $\mathrm{C}(+) / \mathrm{P}$ (slope 0.0036 , with $t$ statistic 3.20) and C/P DUMMY (slope 0.0038, with $t$-statistic 3.01). Overall, it appears that 
$\mathrm{B} / \mathrm{M}, \mathrm{S} / \mathrm{P}, \mathrm{D} / \mathrm{E}, \mathrm{E}(+) / \mathrm{P}$ and $\mathrm{C} / \mathrm{P}$ have a reliably positive influence on subsequent realized returns, with size showing negatively significance.

\section{Multivariate Fama-MacBeth Regressions}

We run multivariate Fama-MacBeth (FM) regressions to further identify the variables that most fundamentally determine average stock returns for Chinese equities. Table 4 presents average slopes and $t$-statistics from a wide range of FM regressions of returns on the group of variables specified.

Table 4

Multivariate Fama-MacBeth regressions of returns on the group of variables specified over the period 1995-2011

\begin{tabular}{|c|c|c|c|c|c|c|c|c|c|c|}
\hline & & Cons & $\mathrm{B} / \mathrm{M}$ & Size & $\mathrm{D} / \mathrm{E}$ & $\mathrm{S} / \mathrm{P}$ & $\mathrm{E}(+) / \mathrm{P}$ & $\begin{array}{l}\text { E/P } \\
\text { DUMM } \\
Y\end{array}$ & $\mathrm{C}(+) / \mathrm{P}$ & $\begin{array}{l}\text { C/P } \\
\text { DUMM } \\
\text { Y }\end{array}$ \\
\hline (A) & B/M, Size & $\begin{array}{l}0.0075 \\
(2.97)\end{array}$ & $\begin{array}{l}0.0053 \\
(3.58)\end{array}$ & $\begin{array}{l}-0.0063 \\
(-2.72)\end{array}$ & & & & & & \\
\hline (B) & $\mathrm{B} / \mathrm{M}, \mathrm{D} / \mathrm{E}$ & $\begin{array}{l}0.0098 \\
(1.74)\end{array}$ & $\begin{array}{l}0.0044 \\
(3.40)\end{array}$ & & $\begin{array}{l}0.0013 \\
(1.24)\end{array}$ & & & & & \\
\hline (C) & S/P, Size & $\begin{array}{l}0.0075 \\
(2.92)\end{array}$ & & $\begin{array}{l}-0.0065 \\
(-2.71)\end{array}$ & & $\begin{array}{l}0.0046 \\
(4.98)\end{array}$ & & & & \\
\hline (D) & $\mathrm{S} / \mathrm{P}, \mathrm{D} / \mathrm{E}$ & $\begin{array}{l}0.0099 \\
(1.40)\end{array}$ & & & $\begin{array}{l}0.0011 \\
(0.76)\end{array}$ & $\begin{array}{l}0.0033 \\
(3.36)\end{array}$ & & & & \\
\hline (E) & $\mathrm{B} / \mathrm{M}, \mathrm{S} / \mathrm{P}$ & $\begin{array}{l}0.0098 \\
(1.75)\end{array}$ & $\begin{array}{l}0.0036 \\
(2.68)\end{array}$ & & & $\begin{array}{l}0.0023 \\
(3.76)\end{array}$ & & & & \\
\hline$(\mathrm{F})$ & Size, D/E & $\begin{array}{l}0.0072 \\
(2.79)\end{array}$ & & $\begin{array}{l}-0.0062 \\
(-2.62)\end{array}$ & $\begin{array}{l}0.0033 \\
(2.56)\end{array}$ & & & & & \\
\hline (G) & $\mathrm{E} / \mathrm{P}, \mathrm{C} / \mathrm{P}$ & $\begin{array}{l}0.0061 \\
(1.84)\end{array}$ & & & & & $\begin{array}{l}0.0022 \\
(2.00)\end{array}$ & $\begin{array}{l}0.0015 \\
(1.17)\end{array}$ & $\begin{array}{l}0.0029 \\
(3.04)\end{array}$ & $\begin{array}{l}0.0032 \\
(3.25)\end{array}$ \\
\hline (H) & B/M, Size, D/E & $\begin{array}{l}0.0076 \\
(3.02)\end{array}$ & $\begin{array}{l}0.0042 \\
(3.40)\end{array}$ & $\begin{array}{l}-0.0063 \\
(-2.75)\end{array}$ & $\begin{array}{l}0.0015 \\
(1.53)\end{array}$ & & & & & \\
\hline (I) & S/P, Size, D/E & $\begin{array}{l}0.0075 \\
(2.95)\end{array}$ & & $\begin{array}{l}-0.0064 \\
(-2.74)\end{array}$ & $\begin{array}{l}0.0010 \\
(0.78)\end{array}$ & $\begin{array}{l}0.0034 \\
(3.74)\end{array}$ & & & & \\
\hline (J) & Size, B/M, S/P & $\begin{array}{l}0.0076 \\
(3.02)\end{array}$ & $\begin{array}{l}0.0035 \\
(2.68)\end{array}$ & $\begin{array}{l}-0.0064 \\
(-2.75)\end{array}$ & & $\begin{array}{l}0.0024 \\
(3.97)\end{array}$ & & & & \\
\hline$(\mathrm{K})$ & Size, B/M, E/P & $\begin{array}{l}0.0081 \\
(3.50)\end{array}$ & $\begin{array}{l}0.0043 \\
(3.00)\end{array}$ & $\begin{array}{l}-0.0067 \\
(-3.05)\end{array}$ & & & $\begin{array}{l}0.0033 \\
(3.70)\end{array}$ & $\begin{array}{l}0.0028 \\
(2.74)\end{array}$ & & \\
\hline (L) & Size, $B / M, C / P$ & $\begin{array}{l}0.0086 \\
(2.88)\end{array}$ & $\begin{array}{l}0.0042 \\
(2.73)\end{array}$ & $\begin{array}{l}-0.0072 \\
(-2.58)\end{array}$ & & & & & $\begin{array}{l}0.0028 \\
(4.16)\end{array}$ & $\begin{array}{l}0.0033 \\
(5.01)\end{array}$ \\
\hline (M) & Size, D/E, E/P & $\begin{array}{l}0.0081 \\
(3.42)\end{array}$ & & $\begin{array}{l}-0.0068 \\
(-3.03)\end{array}$ & $\begin{array}{l}0.0024 \\
(1.99)\end{array}$ & & $\begin{array}{l}0.0035 \\
(3.68)\end{array}$ & $\begin{array}{l}0.0033 \\
(3.14)\end{array}$ & & \\
\hline$(\mathrm{N})$ & Size, D/E, C/P & $\begin{array}{l}0.0085 \\
(2.82)\end{array}$ & & $\begin{array}{l}-0.0072 \\
(-2.55)\end{array}$ & $\begin{array}{l}0.0022 \\
(1.54)\end{array}$ & & & & $\begin{array}{l}0.0033 \\
(4.57)\end{array}$ & $\begin{array}{l}0.0041 \\
(4.77)\end{array}$ \\
\hline (0) & $\begin{array}{l}\text { B/M, Size, S/P, } \\
\text { D/E }\end{array}$ & $\begin{array}{l}0.0076 \\
(3.02)\end{array}$ & $\begin{array}{l}0.0033 \\
(2.75)\end{array}$ & $\begin{array}{l}-0.0063 \\
(-2.76)\end{array}$ & $\begin{array}{l}0.0004 \\
(0.39)\end{array}$ & $\begin{array}{l}0.0019 \\
(2.49)\end{array}$ & & & & \\
\hline (P) & $\begin{array}{l}\text { Size, D/E, E/P, } \\
\text { C/P }\end{array}$ & $\begin{array}{l}0.0089 \\
(3.14)\end{array}$ & & $\begin{array}{l}-0.0075 \\
(-2.76)\end{array}$ & $\begin{array}{l}0.0017 \\
(1.25)\end{array}$ & & $\begin{array}{l}0.0028 \\
(2.68)\end{array}$ & $\begin{array}{l}0.0029 \\
(2.53)\end{array}$ & $\begin{array}{l}0.0027 \\
(4.37)\end{array}$ & $\begin{array}{l}0.0034 \\
(4.72)\end{array}$ \\
\hline (Q) & $\begin{array}{l}\mathrm{B} / \mathrm{M}, \quad \mathrm{S} / \mathrm{P}, \mathrm{E} / \mathrm{P}, \\
\mathrm{C} / \mathrm{P}\end{array}$ & 0.0060 & 0.0029 & & & 0.0021 & 0.0013 & 0.0006 & 0.0012 & 0.0016 \\
\hline (R) & ALL & $\begin{array}{l}(1.88) \\
0.0087 \\
(3.19)\end{array}$ & $\begin{array}{l}(2.04) \\
0.0026 \\
(2.03)\end{array}$ & $\begin{array}{l}-0.0073 \\
(-2.78) \\
\end{array}$ & $\begin{array}{l}0.0000 \\
(0.01)\end{array}$ & $\begin{array}{l}(2.82) \\
0.0016 \\
(1.94)\end{array}$ & $\begin{array}{l}(1.21) \\
0.0027 \\
(2.78)\end{array}$ & $\begin{array}{l}(0.40) \\
0.0022 \\
(2.05)\end{array}$ & $\begin{array}{l}(1.67) \\
0.0018 \\
(3.34)\end{array}$ & $\begin{array}{l}(2.02) \\
0.0023 \\
(3.92)\end{array}$ \\
\hline
\end{tabular}

Table 4-continued

This table reports the coefficients from multivariate Fama-MacBeth regressions over the period January 1995 to December 2011. The coefficients are average time-series OLS estimates 
and the corresponding $t$-values are in parentheses. Monthly excess returns of individual stocks are regressed on various subsets of explanatory variables at the end of each month. B/M is the natural logarithm of the book to market ratio; $\mathrm{D} / \mathrm{E}$ is the natural logarithm of the debt to equity ratio; $\mathrm{S} / \mathrm{P}$ is the natural logarithm of the sales to price ratio; size is the natural logarithm of the market value of tradable shares; $\mathrm{E}(+) / \mathrm{P}$ is the natural logarithm of positive earnings-to-price ratio; $\mathrm{E} / \mathrm{P}$ DUMMY is the natural logarithm of the absolute value of negative earnings to price ratio; $\mathrm{C}(+) / \mathrm{P}$ is the natural logarithm of positive cash flow to price ratio; and $\mathrm{C} / \mathrm{P}$ DUMMY is the natural logarithm of the absolute value of negative cash flow to price ratio. Results for various subsets of independent variables are presented.

In the regression of returns on $\mathrm{B} / \mathrm{M}$ and size, the coefficient on $\mathrm{B} / \mathrm{M}$ is positive and significant (average slope 0.0053 , with $t$-statistic 3.58) (Model $\mathrm{A}$ of Table 4). In the combined regression on $\mathrm{B} / \mathrm{M}$ and $\mathrm{D} / \mathrm{E}$, a significant positive coefficient is again observed for $\mathrm{B} / \mathrm{M}$ (slope 0.0044 , with $t$-statistic 3.40, Model B). Controlling for size and $\mathrm{D} / \mathrm{E}$, we find that $\mathrm{B} / \mathrm{M}$ remains significant $(t$ statistic 3.40, Model $\mathrm{H}$ ). When we replace B/M in Models A and B with S/P, S/P displays a high level of significance ( $t$-statistics of 4.98 and 3.36, respectively, models $C$ and $D)$. Regressions on $\mathrm{S} / \mathrm{P}$ controlling for size and leverage reveal that the coefficient on $\mathrm{S} / \mathrm{P}$ is positive and significant ( $t$-statistic 3.74, Model I).

When returns are regressed simultaneously on $\mathrm{B} / \mathrm{M}$ and $\mathrm{S} / \mathrm{P}$, both $\mathrm{B} / \mathrm{M}$ and $\mathrm{S} / \mathrm{P}$ are positive and significant ( $t$-statistics of 2.68, and 3.76, respectively, Model E). When size is added as a third independent variable, $t$-statistics for both $\mathrm{B} / \mathrm{M}$ and $\mathrm{S} / \mathrm{P}$ remain positively significant and size has negative significance ( $t$-statistic -2.75 , Model J). Augmenting Model J with leverage suppresses the explanatory power of S/P (the average slope on S/P has decreased from 0.0024 to 0.0019 and the $t$-statistic declines from 3.97 to 2.49, Model 0).

Consistent with the findings of Table 3 , we find negatively significant coefficient on size even when other explanatory variables are incorporated in the model (models A, C, F, H to P and R). Leverage also remains insignificant across all regressions (models $\mathrm{B}, \mathrm{D}, \mathrm{H}, \mathrm{I}, \mathrm{N}$ to $\mathrm{P}$ and $\mathrm{R}$ ). In other words, leverage has little explanatory power in explaining stock returns in the Chinese market. Model G of Table 4 presents the regression of returns on $\mathrm{E}(+) / \mathrm{P}$ and $\mathrm{E} / \mathrm{P}$ DUMMY and $\mathrm{C}(+) / \mathrm{P}$ and $\mathrm{C} / \mathrm{P}$ DUMMY. Combining $\mathrm{C} / \mathrm{P}$ and $\mathrm{E} / \mathrm{P}$ has not greatly affected their predictive power compared to the univariate regressions (Table 3) (with the one exception that the significance of $\mathrm{E}(+) / \mathrm{P}$ is somewhat reduced). Thus, $\mathrm{E}(+) / \mathrm{P}$ retains a positive and significant coefficient (at the 5\% level); E/P DUMMY remains insignificant; and both $\mathrm{C}(+) / \mathrm{P}$ and $\mathrm{C} / \mathrm{P}$ DUMMY are significant (at the $1 \%$ level). In Models $\mathrm{K}$ and $\mathrm{L}$, controlling for $\mathrm{B} / \mathrm{M}$ and size, $\mathrm{E}(+) / \mathrm{P}, \mathrm{E} / \mathrm{P}$ DUMMY, $\mathrm{C}(+) / \mathrm{P}$ and $\mathrm{C} / \mathrm{P}$ DUMMY retain significant power in explaining stock returns. Notably, it appears that the explanatory power of book-to-market is not being subsumed by the influence of the $\mathrm{E} / \mathrm{P}(\mathrm{E}(+) / \mathrm{P}$ and $\mathrm{E} / \mathrm{P} \mathrm{DUMMY})$ and $\mathrm{C} / \mathrm{P}(\mathrm{C}(+) / \mathrm{P}$ and $\mathrm{C} / \mathrm{P}$ DUMMY).

Models $\mathrm{M}$ and $\mathrm{N}$ in Table 4 allow for regressions on $\mathrm{E} / \mathrm{P}$ and $\mathrm{C} / \mathrm{P}$, controlling for leverage and size. Results of these two regressions show strong relationship between stock returns and $\mathrm{E} / \mathrm{P}$ $(\mathrm{E}(+) / \mathrm{P}$ and $\mathrm{E} / \mathrm{P}$ DUMMY) and $\mathrm{C} / \mathrm{P}(\mathrm{C}(+) / \mathrm{P}$ and $\mathrm{C} / \mathrm{P}$ DUMMY $)$. Model $\mathrm{P}$ provides a comparison of the regressions on $\mathrm{C} / \mathrm{P}$ and $\mathrm{E} / \mathrm{P}$ separately (Models $\mathrm{M}$ and $\mathrm{N}$ ) with $\mathrm{C} / \mathrm{P}$ and $\mathrm{E} / \mathrm{P}$ jointly (after controlling for both $\mathrm{D} / \mathrm{E}$ and size). As in models $\mathrm{M}$ and $\mathrm{N}$, significant positive coefficients on $\mathrm{E}(+) / \mathrm{P}, \mathrm{E} / \mathrm{P}$ DUMMY, $\mathrm{C}(+) / \mathrm{P}$ and $\mathrm{C} / \mathrm{P}$ DUMMY are observed, although their $t$-statistics have slightly decreased. In these regressions size remains negatively significant, while leverage is significant in Model M and then changes to insignificant in Models $\mathrm{N}$ and $\mathrm{P}$. 
Model $Q$ in Table 4 determines which variables best capture the value effect. In this model we include all proxies while omitting leverage and size. S/P has the highest level of significance $(t$ statistic 2.82) of the variables (B/M, S/P, E/P and C/P). Both $\mathrm{B} / \mathrm{M}$ and $\mathrm{C} / \mathrm{P}$ DUMMY remain significant ( $t$-statistics of 2.04 and 2.02 , respectively). Thus, the power of the $\mathrm{S} / \mathrm{P}$ and $\mathrm{B} / \mathrm{M}$ ratio dominates that of the $\mathrm{E} / \mathrm{P}$ and $\mathrm{C} / \mathrm{P}$ variables. This multivariate regression finding confirms that value stocks have higher fundamentally risk than growth stocks. In the full model (Model R), only the coefficient on $\mathrm{D} / \mathrm{E}$ is insignificant ( $t$-statistic 0.01 ). In all regressions incorporating the $C / P$ variable $(G, L, N, P, Q$ and $R), C / P$ DUMMY is significant and $C(+) / P$ is significant in Models G, L, N, P and R. Size is negatively significant across all regressions; leverage, however, are insignificant across most of regressions. ${ }^{11}$

\section{Divergence of Opinion and Stock Returns}

To investigate why value stocks have superior returns relative to growth stocks, we follow Doukas et al. (2004) and link the divergence of opinion with value stock performances. Specifically, Table 5 shows the mean and median values of the divergence of opinion variable for portfolios formed after sorting stocks into 9 portfolios on the intersection of the size and $\mathrm{B} / \mathrm{M}$ tritiles. The mean value of forecast dispersion is 0.2408 for the smallest size/highest $\mathrm{B} / \mathrm{M}$ portfolio and 0.1211 for the biggest size/lowest $\mathrm{B} / \mathrm{M}$ portfolio. We also show that small stocks have higher disagreement than big stocks $\left(Q_{3}-Q_{1}\right.$ for all companies is -0.0061), and value stocks have higher investor disagreement than growth stocks $\left(Q_{3}-Q_{1}\right.$ for all companies is 0.0537). These findings are consistent with Doukas et al. (2004) who show that small-cap and high-B/M stocks are subject to more heterogeneous beliefs among investors than large-cap and low-B/M stocks in the U.S. market.

Table 5

Dispersion of analyst forecasts for portfolios formed independently on size and B/M from 1995 to 2011

\begin{tabular}{|c|c|c|c|c|c|}
\hline \multirow[b]{2}{*}{ B/M Tritile } & \multicolumn{4}{|c|}{$\begin{array}{l}\text { Size } \\
\text { Tritile }\end{array}$} & \multirow[b]{2}{*}{$\mathrm{Q}_{3}-\mathrm{Q}_{1}$} \\
\hline & $\mathrm{Q}_{1}($ small $)$ & $\mathrm{Q}_{2}$ & $\mathrm{Q}_{3}$ (big) & $\begin{array}{l}\text { All } \\
\text { companies }\end{array}$ & \\
\hline \multirow[t]{2}{*}{$\mathrm{Q}_{1}$ (low) } & 0.1464 & 0.1214 & 0.1211 & 0.1358 & -0.0061 \\
\hline & [0.1469] & {$[0.1230]$} & [0.1213] & [0.1365] & {$[-0.0051]$} \\
\hline \multirow[t]{2}{*}{$\mathrm{Q}_{2}$} & 0.1847 & 0.1359 & 0.1289 & 0.1535 & -0.0937 \\
\hline & {$[0.1846]$} & {$[0.1365]$} & [0.1300] & [0.1539] & {$[-0.3834]$} \\
\hline $\mathrm{Q}_{3}$ (high) & 0.2408 & 0.1999 & 0.1776 & 0.2034 & -0.0452 \\
\hline \multirow{3}{*}{$\begin{array}{l}\text { All } \\
\text { companies }\end{array}$} & [0.2437] & [0.2027] & [0.1719] & [0.2026] & {$[-0.0406]$} \\
\hline & 0.1956 & 0.1556 & 0.1446 & 0.1638 & -0.0425 \\
\hline & [0.1973] & [0.1573] & [0.1430] & [0.1640] & {$[-0.0566]$} \\
\hline $\mathrm{Q}_{3}-\mathrm{Q}_{1}$ & 0.0937 & 0.0606 & 0.0308 & 0.0537 & \\
\hline
\end{tabular}

\footnotetext{
11 We test the turn-of-the-year effect in the Chinese market, by replicating the original portfolio and regression analyses on (a) all months excluding January and February, and (b) just the months of January and February. Our results for the turn of the year effect are identical to the full-sample results and thus we advance that our findings are not driven by seasonal influences.
} 
This table reports mean and [median] values of dispersion for portfolio formed on size and $\mathrm{B} / \mathrm{M}$. At the end of June of each year $t$, stocks are sorted in three groups based on market value of tradable shares, and stocks are allocated in an independent sort to three groups based on B/M. Nine size-B/M portfolios are the intersections of the three market value and the three $\mathrm{B} / \mathrm{M}$ groups. Dispersion is defined as the ratio of the standard deviation of annual earnings per share forecasts to the absolute value of the mean forecast, as reported in the I/B/E/S Summary History File

To ensure that these results are not the outcome merely of analyst coverage, we sort stocks into 27 groups based on size, B/M and the number of analyst forecasts (NAF). Table 6 presents the mean and median values of DISP for each of the 27 portfolios. Controlling for size and analyst coverage, we establish that higher $\mathrm{B} / \mathrm{M}$ portfolios retain a higher level of dispersion of analyst forecasts than lower B/M portfolios. In other words, the value-minus-growth portfolios tend to retain positive values of forecast dispersion. For example, in the case of small firms with a low level of analyst following, value (growth) portfolios have a mean dispersion measure of $0.2465(0.1500)$ producing a High-Low difference of 0.0965 . This evidence further supports our findings from Table 5 that regardless of the analyst coverage, the small-cap and high-B/M firms appear to have higher investor disagreement than large and low-B/M firms.

Table 6

Dispersion of analyst forecasts for portfolios of stocks sorted independently on size, $\mathrm{B} / \mathrm{M}$ and the number of analysts from 1995 to 2011

\begin{tabular}{|c|c|c|c|c|c|c|c|c|c|}
\hline \multirow{3}{*}{$\mathrm{B} / \mathrm{M}$} & \multicolumn{9}{|c|}{ Size } \\
\hline & \multirow[b]{2}{*}{ Low } & \multirow{2}{*}{$\begin{array}{l}\text { Small } \\
\text { Medium }\end{array}$} & \multirow[b]{2}{*}{ High } & \multirow[b]{2}{*}{ Low } & \multirow{2}{*}{$\begin{array}{l}\text { Medium } \\
\text { Medium }\end{array}$} & \multirow[b]{2}{*}{ High } & \multirow[b]{2}{*}{ Low } & \multirow{2}{*}{$\begin{array}{l}\text { Big } \\
\text { Medium }\end{array}$} & \multirow[b]{2}{*}{ High } \\
\hline & & & & & & & & & \\
\hline & $\mathrm{NAF}$ & NAF & NAF & NAF & NAF & NAF & NAF & NAF & NAF \\
\hline \multirow[t]{2}{*}{ Low } & 0.1500 & 0.1120 & 0.1044 & 0.1383 & 0.1001 & 0.0960 & 0.1254 & 0.1180 & 0.0930 \\
\hline & [0.1510] & [0.1127] & [0.1048] & [0.1392] & {$[0.1016]$} & {$[0.0974]$} & [0.1273] & [0.1192] & [0.0932] \\
\hline \multirow[t]{2}{*}{ Medium } & 0.2006 & 0.1333 & 0.1140 & 0.1732 & 0.1195 & 0.1161 & 0.1526 & 0.1244 & 0.0964 \\
\hline & [0.1983] & [0.1339] & [0.1166] & [0.1767] & [0.1207] & [0.1157] & [0.1524] & [0.1255] & [0.0969] \\
\hline \multirow[t]{2}{*}{ High } & 0.2465 & 0.2412 & 0.1519 & 0.2152 & 0.1703 & 0.1387 & 0.2048 & 0.1648 & 0.1210 \\
\hline & [0.2475] & [0.2413] & [0.1524] & [0.2143] & [0.1629] & [0.1388] & [0.2051] & [0.1752] & [0.1214] \\
\hline \multirow[t]{2}{*}{ All } & 0.2124 & 0.1825 & 0.1316 & 0.1977 & 0.1367 & 0.1151 & 0.1698 & 0.1255 & 0.1183 \\
\hline & [0.2123] & [0.1883] & [0.1317] & [0.1968] & {$[0.1353]$} & [0.1154] & [0.1699] & [0.1291] & [0.1192] \\
\hline \multirow[t]{2}{*}{ High-Low } & 0.0864 & 0.1154 & 0.0424 & 0.0801 & 0.0508 & 0.0432 & 0.0787 & 0.0554 & 0.0271 \\
\hline & {$[0.0854]$} & {$[0.1175]$} & [0.0437] & {$[0.0800]$} & {$[0.0434]$} & [0.0417] & {$[0.0765]$} & {$[0.0551]$} & [0.0245] \\
\hline
\end{tabular}

This table reports the mean and [median] values of dispersion for 27 portfolios formed on size, $\mathrm{B} / \mathrm{M}$ and number of analysts from 1995 to 2011. At the end of June of each year t, stocks are 
equally sorted into three groups based on market value, and stocks are allocated in an independent sort to three groups based on B/M. Nine size-B/M portfolios are the intersections of the three market value and the three B/M groups. Each size and B/M group is further sorted into three dispersion groups. Dispersion is defined as the ratio of the standard deviation of annual earnings per share forecasts to the absolute value of the mean forecast, as reported in the I/B/E/S Summary History File.

To further test our predictions, we run the Carhart four-factor model with and without the disagreement risk factor (DRF). Table 7 reports the results for regressions in which the test portfolio is high $\mathrm{B} / \mathrm{M}$, low $\mathrm{B} / \mathrm{M}$, small size, and big size, as well as regressions for the valueminus-growth and small-minus-big portfolios. Panels $A$ and $B$ in Table 7 show that the coefficient on DRF is positive and significant $(0.1174, t$-statistic 4.48$)$ for the portfolio of value stocks (high $\mathrm{B} / \mathrm{M})$, but is negative and significant $(-0.2124, t$-statistic -4.17$)$ for growth stocks (low $\mathrm{B} / \mathrm{M}$ ). When we incorporate the DRF variable, the $\mathrm{R}$ square increases for value portfolios (from 0.82 to 0.89 ) and growth portfolios (from 0.90 to 0.92 ).

In Panel $\mathrm{E}$ we show that the coefficient on DRF is positive and significant. It is worth noting that in the five-factor model, the coefficient for the DRF is the largest and has the highest significance and the R square improves from 0.88 to 0.93 . This indicates that the divergence of opinion plays a central role in explaining the superior returns of value stocks. This evidence is also strongly consistent with Doukas et al. (2004) who document thaf the disagreement risk factor is positively associated with value stock returns, but negatively related with the returns for growth stocks. The results in Panels $\mathrm{C}$ and D show a positive and significant relationship between average returns and the dispersion factor for the smallest stocks (average slope 0.2933 , with a $t$-statistic of 5.08), and a negative and significant relationship for the largest stocks(average slope -0.0919 , with a $t$-statistic of -3.91).

Panel F presents the regressions of returns for the small-minus-big portfolio. Here, we observe that returns are positively and insignificantly related to dispersion in analysts' forecasts $(t-$ statistic 3.67). The coefficients and their significance on DRF for small, big, and small-minusbig portfolios are much lower than those for high, low, and high-minus-low portfolios; similarly, the spreads in the improvement of $\mathrm{R}$ square for portfolios based on size are smaller than those based on B/M. 
Table 7

Time-Series tests of three- and four-factor models for high-B/M, low-B/M, small, and big portfolios from 1995 to 2011

\begin{tabular}{|c|c|c|c|c|c|c|c|}
\hline Subsample & $a$ & $b \mathrm{RMF}$ & $s S M B$ & $h \mathrm{HML}$ & $m \mathrm{MOM}$ & $d \mathrm{DRF}$ & $\begin{array}{l}\text { Adjusted } \\
R^{2}\end{array}$ \\
\hline \multicolumn{8}{|l|}{ A. High B/M } \\
\hline & $\begin{array}{l}-0.0012 \\
(-1.67)\end{array}$ & $\begin{array}{l}0.9878 \\
(42.50)\end{array}$ & $\begin{array}{l}0.0622 \\
(3.82)\end{array}$ & $\begin{array}{l}0.5213 \\
(28.15)\end{array}$ & $\begin{array}{l}0.0844 \\
(4.43)\end{array}$ & & 0.8206 \\
\hline & $\begin{array}{l}-0.0012 \\
(-1.42)\end{array}$ & $\begin{array}{l}0.9820 \\
(36.32)\end{array}$ & $\begin{array}{l}0.0812 \\
(4.16)\end{array}$ & $\begin{array}{l}0.5972 \\
(19.75)\end{array}$ & $\begin{array}{l}0.0645 \\
(3.24)\end{array}$ & $\begin{array}{l}0.1174 \\
(4.48)\end{array}$ & 0.8929 \\
\hline \multicolumn{8}{|l|}{ B. Low B/M } \\
\hline & $\begin{array}{l}0.0002 \\
(0.25)\end{array}$ & $\begin{array}{l}1.0095 \\
(40.65)\end{array}$ & $\begin{array}{l}0.0143 \\
(1.72)\end{array}$ & $\begin{array}{l}-0.5275 \\
-23.28\end{array}$ & $\begin{array}{c}-0.0094 \\
(-0.60)\end{array}$ & & 0.9012 \\
\hline & 0.0014 & 1.0221 & 0.0399 & -0.7235 & 0.0172 & -0.2124 & 0.9209 \\
\hline \multicolumn{8}{|l|}{ C. Small } \\
\hline & 0.0016 & 10174 & 0.9880 & -0.0404 & 0.0317 & & 0.8904 \\
\hline & $(2.20)$ & $(50.17)$ & $(26.14)$ & $(-2.02)$ & (2.88) & & \\
\hline & 0.0017 & 1.0151 & 1.0513 & -0.1047 & 0.0288 & 0.2933 & 0.9143 \\
\hline & $(1.90)$ & $(38.50)$ & $(23.22)$ & $(-3.42)$ & $(2.53)$ & (5.08) & \\
\hline \multicolumn{8}{|l|}{ D. Big } \\
\hline & 0.0004 & 1.0114 & -0.2686 & -0.0080 & 0.0182 & & 0.8668 \\
\hline & $(0.93)$ & (60.91) & $(-24.45)$ & $(-2.64)$ & $(1.73)$ & & \\
\hline & 0.0005 & 0.9946 & -0.2029 & 0.0351 & 0.0150 & -0.0919 & 0.8729 \\
\hline & $(1.45)$ & $(63.30)$ & $(-25.44)$ & $(2.84)$ & $(1.96)$ & $(-3.91)$ & \\
\hline \multicolumn{8}{|c|}{ E. High B/M-Low B/M } \\
\hline & -0.0039 & -0.0223 & 0.0482 & 1.0431 & 0.0990 & & 0.8757 \\
\hline & $\begin{array}{l}(-3.3 /) \\
-0.0048\end{array}$ & $\begin{array}{l}(-1.19) \\
-0.0385\end{array}$ & $\begin{array}{l}(1.7 /) \\
0.0403\end{array}$ & $\begin{array}{l}33 . / 0) \\
1.3177\end{array}$ & $\begin{array}{l}(3.80) \\
0.0467\end{array}$ & 0.4488 & 0.9252 \\
\hline & $(-4.01)$ & $(-3.08)$ & $(1.52)$ & $(32.16)$ & $(1.85)$ & $(6.35)$ & \\
\hline \multicolumn{8}{|l|}{ F. Small-Big } \\
\hline & -0.0013 & 0.0054 & 1.2569 & -0.0381 & 0.0083 & & 0.8285 \\
\hline & $(-1.87)$ & $(0.71)$ & (75.64) & $(-2.01)$ & $(0.52)$ & & \\
\hline & -0.0010 & 0.0221 & 1.2532 & -0.1428 & 0.0145 & 0.0178 & 0.8776 \\
\hline & $(-1.06)$ & $(2.23)$ & (59.91) & $(-4.40)$ & $(0.73)$ & (3.67) & \\
\hline
\end{tabular}

The table reports estimates of the Carhart four-factor model, and a five-factor model $R_{p t}-R_{f t}=a_{p t}+b_{p}\left(R_{M t}-R_{f t}\right)+s_{p} S M B_{t}+h_{p} H M L_{t}+m_{p} M O M_{t}+d_{p} D R F_{t}+\varepsilon_{p t}$ for monthly excess returns on high $\mathrm{B} / \mathrm{M}$, low $\mathrm{B} / \mathrm{M}$, small and big portfolios, as well as two zero-cost portfolios based on $\mathrm{B} / \mathrm{M}$ and size (High-Low and Small-Big). The sample period is July 1995 to December 2011 and $t$ statistics are in parentheses. Adjust R square value for each model is also reported. Stocks are allocated into 3 equal sized groups based on $\mathrm{B} / \mathrm{M}$ at the end of June of each year $t$ to form high B/M, low B/M and high-low B/M portfolios. Similarly, stocks are also sorted into 3 equal sized groups on market value of tradable shares at the end of June of each year $t$ to form small, big and small-big porfolios. The variables $R_{m}-R_{f}$, SMB and HML are calculated using the same methodology as Fama and French (1996). The momentum factor (MOM) is the return on the mimicking portfolio for the momentum factor as Carhart (1997) proposed. The dispersion premium (DRF) is the difference between the return on a portfolio comprised of stocks with high dispersion and the return on a portfolio comprised of stocks with low dispersion. Dispersion is defined as in Tables 5 and 6. 
Table 8

System Tests of Asset Pricing Models

\begin{tabular}{lccccccc}
\hline & & & & & & MLRT, \\
& GMM & $\lambda_{\mathrm{m}}$ & $\lambda_{\text {SMB }}$ & $\lambda_{\text {HML }}$ & $\lambda_{\text {MоM }}$ & $\lambda_{\text {DOF }}$ & $\mathrm{H}_{0}: \mathrm{d}_{\mathrm{p}}=0$ \\
\hline Carhart & 24.62 & 0.0152 & 0.0168 & 0.0285 & 0.0009 & & \\
& $(0.9990)$ & $(2.36)$ & $(5.09)$ & $(7.17)$ & $(0.48)$ & & \\
Carhart DRF & 22.93 & 0.0160 & 0.0186 & 0.0304 & 0.0015 & 0.0221 & 3.87 \\
& $(0.9995)$ & $(2.11)$ & $(4.35)$ & $(5.84)$ & $(0.63)$ & $(2.79)$ & $(0.0073)$ \\
\hline
\end{tabular}

The test of the divergence of opinion augmented Carhart model is based on the following systems:

$$
\begin{aligned}
& r_{p t}=b_{p} r_{m t}+s_{p} S M B_{t}+h_{p} H M L_{t}+m_{p} M O M_{t}+d_{p} D R F_{t}+\varepsilon_{p t} \quad[\mathrm{p}=1,2, \ldots, \mathrm{N}] \\
& r_{m t}=\lambda_{m t}+\xi_{b t} \\
& S M B_{t}=\lambda_{S M B}+\xi_{s t} \\
& H M L_{t}=\lambda_{H M L}+\xi_{h t} \\
& M O M_{t}=\lambda_{M O M}+\xi_{m t} \\
& D R F_{t}=\lambda_{D R F}+\xi_{d t}
\end{aligned}
$$

This table reports the GMM test statistic, the estimates of each factor premium and the MLRT statistic. The associated $t$-statistics are reported in parentheses below GMM, each coefficient estimate and MRLT statistic. The sample period is from 1995 to 2011

Table 8 presents the results of GMM system regressions by testing the Carhart and divergence of opinion augmented Carhart (Carhart DRF) models. We report the results of the system regression for the Carhart model in Table 8. We find the factor premiums for the market, size and book-to-market factors are positive and significant at the 5 percent and 1 percent levels respectively. We also find that the premium for the momentum factor is positive, but insignificant ( $t$-statistic of 0.48). Table 8 also presents the results of system regression for the augmented Carhart DRF model. Our results for the Carhart model and the augmented Carhart model are similar in that the premiums for the market factor $\left(\lambda_{m}\right)$, size $\left(\lambda_{S M B}\right)$ and book-tomarket $\left(\lambda_{\mathrm{HML}}\right)$ are positive and significant ( $t$-statistic of $2.11,4.35$, and 5.84 , respectively), and the premium for the momentum factor $\left(\lambda_{\text {Mом }}\right)$ is positive but insignificant $(t$-statistic of 0.63$)$. We also report that the factor premium for DRF $\left(\lambda_{\mathrm{DRF}}\right)$ is positive and significant $(t$-statistic of 2.79). In the last column we report the Modified Likelihood Ratio Test (MLRT) statistic which rejects the hypothesis that all parameters are equal to zero. This clearly indicates that DRF is useful in pricing assets and is a proxy for risk.

Overall, we find that value stocks generate significant superior returns relative to growth stocks and the divergence of opinion is related to such superior returns.

\section{CONCLUSIONS}

Prior studies on the performances of value stocks and growth stocks has been conducted mostly in developed markets (U.S., Japan, UK and Australia). Our study provides much needed out of sample evidence on whether value stocks outperform growth stocks. Our findings reveal that value stocks outperform growth stocks when portfolios are formed on book-tomarket, sales-to-price, earnings-to-price, and cash-flow-to-price (with only a weak relationship between leverage and average stock returns). Our regression analyses confirm that these variables have individual significant power in explaining stock returns. 
As well as concluding that value stocks generate superior returns to growth stocks in China, we present new evidence that such outperformance of value stocks is related positively to investor uncertainty. This evidence is confirmed by our asset-pricing analysis where we show that divergence of investor opinion shows significant explanatory power. The insights revealed by our findings indicate the need for further research into the dynamics of share price formation in emerging markets and their degree of conformity with more developed markets.

\section{References}

Ackert, L.F., Athanassakos, G., 1997. Prior uncertainty, analyst bias and subsequent abnormal returns. Journal of Financial Research 20, 263-273.

Barbee, W.C., Mukherji, S., Raines, G., 1996. Do sales-price and debt-equity explain stock returns better than bookmarket and firm size? Financial Analysts Journal 52, 56-60.

Beltratti, A., Bortolotti, B., 2006. The non-tradable share reform in the Chinese stock market. Working paper, University of Fondazione Eni Enrico Mattei, Italy.

Black, F., 1993. Beta and return. Journal of Portfolio Management 20, 8-18.

Berkman, H., Dimitrov, V., Jain, P.C., Koch, P.D., Tice, S., 2009. Sell on the news: Difference of opinion, short-sales constraints and returns around earnings announcements. Journal of Financial Economics 92, 376-399.

Carhart, M., 1997. On persistence in mutual fund performance. Journal of Finance 52, 57-82.

Chan, L., Hamao,Y., Lakonishok,J.,1991. Fundamentals and stock returns in Japan. Journal of Finance 46, 17391789.

Chan, H.W.H., Faff, R.W., 2003. An investigation into the role of liquidity in asset pricing: Australian evidence. Pacific-Basin Finance Journal 11, 555-572.

Chang, E.C., Cheng, J.W., Yu, Y., 2007. Short-sales constraints and price discovery: Evidence from the Hong Kong market. Journal of Finance 62, 2097-2122.

Connor, G., Korajczyk, R.A., 1988. Risk and return in an equilibrium APT. Journal of Financial Economics 21, 255289.

Davis, J., 1994. The cross-section of realized stock returns: the pre-Compustat evidence. Journal of Finance 49, 1579-1593.

Diether, K.B., Malloy, C.J., Scherbina, A., 2002. Differences of opinion and the cross section of stock returns. Journal of Finance 57, 2113-2141.

Diamond, D., Verrecchia, R., 1987. Constraints on short-selling and asset price adjustment to private information. Journal of Financial Economics 18, 277-311.

Doukas, J.A., Kim, C., Pantzalis, C., 2002. A test of the error-in-expectations explanation of the value/glamour stock returns performance: Evidence from analysts' forecasts. Journal of Finance 57, 2143-2165.

Doukas, J.A., Kim, C., Pantzalis, C., 2004. Divergent opinions and the performance of value stocks. Financial Analysts Journal 60, 55-64.

Doukas, J.A., Kim, C., Pantzalis, C., 2006a. Divergence of opinion and equity returns. Journal of Financial and Quantitative Analysis 41, 573-606.

Doukas, J.A., Kim, C., Pantzalis, C., 2006b. Divergence of opinion and equity returns under different states of earnings expectations. Journal of Financial Markets 9, 310-331.

Drew, M.E., Naughton, T., Veeraraghavan, M., 2003. Firm size, book to market equity and security returns: evidence from the Shanghai Stock Exchange. Australian Journal of Management 28, 119-140.

Eun, C.S., Huang, W., 2007. Asset pricing in China's domestic stock markets: is there a logic? Pacific-Basin Finance Journal 15, 434-451.

Faff, R.W., 1992. A multivariate test of an equilibrium APT with time varying risk premia in the Australian equity market. Australian Journal of Management 17, 233-258.

Faff, R.W., 2001. An examination of the Fama and French three-factor model using commercially available factors. Australian Journal of Management 26, 1-12. 
Fama, E.F., French, K.R., 1992. The cross-section of expected stock returns. Journal of Finance 47, 427-465.

Fama, E.F., French, K.R., 1993. Common risk factors in the returns on stocks and bonds. Journal of Financial Economics 33, 3-56.

Fama, E.F., French, K.R., 1996. Multifactor explanations of asset pricing anomalies. Journal of Finance 51, 55-84.

Fama, E.F., French, K.R., 1998. Value versus growth: the international evidence. Journal of Finance 53, 1975-2000.

Garfinkel, J.A., Sokobin, J., 2006. Volume, opinion divergence and returns: A study of post-earnings announcement drift. Journal of Accounting Research 44, 85-112.

Gharghori,P., Stryjkowski, S., Veeraraghavan, M., 2012. Value Versus Growth: Australian Evidence. Accounting and Finance 53, 393-417.

Gharghori,P., See, Q., Veeraraghavan, M., 2011. Difference of Opinion and the Cross-section of equity returns: Australian evidence,.Pacific-Basin Finance Journal 19, 435-446..

Hintikka, M., 2008. Market reactions to differences of opinion. Working Paper, The Swedish School of Economics and Business Administration.

Kang, J., Liu, M., Ni, X.S., 2002. Contrarian and momentum strategies in the China stock market: 1993-2000. Pacific-Basin Finance Journal 10, 243-265.

Kothari, S.P., Shanken, J., Sloan, R.G., 1995. Another look at the cross-section of expected stock returns. Journal of Finance 50, 185-224.

Kwag, S.W., Lee, S.W., 2006. Value investing and the business cycle. Journal of Financial Planning 19, 425-442.

Lakonishok, J., Shleifer, A., Vishny,R.W., 1994. Contrarian investment, extrapolation, and risk. Journal of Finance 49. 1541-1578.

La Porta, R., 1996. Expectations and the cross-section of stock returns. Journal of Finance 51, 1715-1742.

La Porta, R., Lakonishok, J., Shleifer, A., Vishny, R., 1997. Good news for value stocks: further evidence on market efficiency. Journal of Finance 52, 859-874.

Leippold, M., Lohre, H., 2008. The dispersion effect in international stock returns, Working Paper, Imperial College, London.

Leledakis, G., Davidson, I., 2001. Are two factors enough? The UK evidence. Financial Analysts Journal 57, 96-105.

Li, G., 2008. China's stock market:inefficiencies and institutional implications. China \& World Economy 16, 81-96.

Ma, S., Faff, R., 2007. Market conditions and the optimal IPO allocation mechanism in China. Pacific-Basin Finance Journal 15, 121-139.

MacKinlay, A.C., 1995. Multifactor models do not explain deviations from CAPM. Journal of Financial Economics 38, 3-28.

Miller, E.M., 1977. Risk, uncertainty, and divergence of opinion. Journal of Finance 32, 1151-1168.

Ng, L., Wu, F., 2006. Revealed stock preferences of individual investors: evidence from Chinese equity markets. Pacific-Basin Finance Journal 14, 175-192.

$\mathrm{Ng}, \mathrm{L} ., \mathrm{Wu}, \mathrm{F} ., 2$ 2007. The trading behavior of institutions and individuals in Chinese equity markets. Journal of Banking \& Finance 31, 2695-2710.

Poon, W., Firth, M., Fung, H., 1998. Asset pricing in segmented capital markets: Preliminary evidence from Chinadomiciled companies. Pacific-Basin Finance Journal 6, 307-319.

Sun, Q., Chong, T., 2007. Determining the contributions to price discovery for Chinese cross-listed stocks. PacificBasin Finance Journal 15, 140-153.

Sun, Q., Tong, W.H.S., 2003. China share issue privatization: the extent of its success. Journal of Financial Economics 70, 183-222.

Varian, H.R., 1985. Divergence of opinion in complete markets: A note. Journal of Finance 40, 309-317.

Wang, Y., Di Iorio, A.D., 2007. The cross section of expected stock returns in the Chinese A-share market. Global Finance Journal 17, 335-349.

Williams, J.T. 1977. Capital Asset Prices with Heterogeneous Beliefs. Journal of Financial Economics5, 219-239 